Discussion Paper No. 04-75

\title{
Capital Control, Debt Financing and Innovative Activity
}

Dirk Czarnitzki and Kornelius Kraft

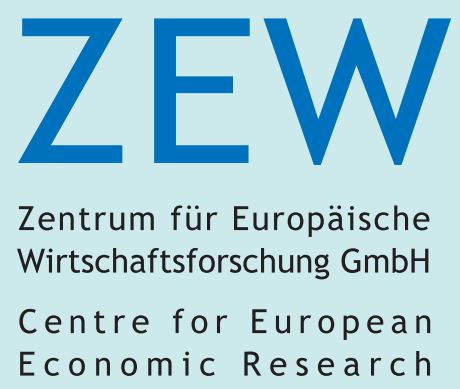


Discussion Paper No. 04-75

\section{Capital Control, Debt Financing and Innovative Activity}

Dirk Czarnitzki and Kornelius Kraft

Download this ZEW Discussion Paper from our ftp server:

ftp://ftp.zew.de/pub/zew-docs/dp/dp0475.pdf

Die Discussion Papers dienen einer möglichst schnellen Verbreitung von neueren Forschungsarbeiten des ZEW. Die Beiträge liegen in alleiniger Verantwortung der Autoren und stellen nicht notwendigerweise die Meinung des ZEW dar.

Discussion Papers are intended to make results of ZEW research promptly available to other economists in order to encourage discussion and suggestions for revisions. The authors are solely responsible for the contents which do not necessarily represent the opinion of the ZEW. 


\section{Non-technical Summary}

It is generally accepted that technical progress, along with human capital, has a major impact for the wealth and long-term growth of industrialized countries. Since Knight, Schumpeter and the beginning of the discussion on innovation, great emphasis has been placed on the central role of the entrepreneur in this process. It seems to be generally accepted that the market is an entrepreneurial process, a learning process is central to the market, and entrepreneurial activities are creative acts of discovery. In stark contrast to these statements on the entrepreneurs, large firms are led by managers nowadays, which leads to a classical principal-agent problem. It is questionable whether managers always act in the interest of the capital owners. On the one hand, many firms may be owned by people or cooperations that hold a major share of the capital. In this case, one could argue that the managers of those firms are monitored by the shareholders and their major actions and decisions are closely controlled. On the other hand, firms with widely held stock are usually assumed to be insufficiently controlled by the shareholders. Each shareholder faces the well-known free-rider problem, as the benefits of an initiative monitoring the manager by one shareholder aimed at improving the quality of management will be enjoyed by all other shareholders. The consequence will be underinvestment into monitoring the management. It remains to be investigated what consequences this has for the innovation process.

First the paper discusses theoretically the incentive mechanisms driving innovation in managerial firms. There are opposing effects at work, and it is a priori unclear which incentive mechanism outweighs the other. On the one hand, managers might be reluctant to invest in innovation activity due to the inherent risk of failure. On the other hand, managers might invest above the profit-maximizing level into R\&D activities, as it is a source of firm growth and the managers' salaries usually depend not only on profits but on growth, too. In this line, debt financing is interesting to study. In the case where the positive growth incentive outweighs the risk argument influencing innovation negatively, insufficiently controlled managers might be disciplined by the credit market.

We then report the results of an empirical study on the effects of the concentration of capital shares and debt financing on innovative activity. For this purpose, a database on German manufacturing firms is used. In total we use information on 275 firms for the years 1982 to 1996 , which leads to 2,793 observations. Innovation is specified by the number of patent applications per year.

It turns out that companies with widely held capital stock are more active in innovation, i.e. weakly controlled managers show a higher innovation propensity. This supports the hypothesis that the positive growth incentive is dominating the negative risk incentive. However, the higher the debt ratio, the more disciplined the managers are. 


\title{
Capital Control, Debt Financing and Innovative Activity
}

\author{
Dirk Czarnitzki* and Kornelius Kraft**
}

October 2004

\begin{abstract}
The present paper first discusses theoretically the different incentives of manager- versus owner-controlled firms for investment into innovative activity. In addition, the role of debt financing is analyzed. Subsequently the results from an empirical study on the determinants of innovative activity measured by patent applications are presented. A sample of German firms covering 2,793 observations is used, and it turns out that companies with widely held capital stock are more active in innovation, i.e. weakly controlled managers show a higher innovation propensity. However, the higher the leverage the more disciplined the managers are.
\end{abstract}

Keywords: Innovation, Patents, Corporate Governance, Limited Dependent Variables JEL-Classification: C25, L11, O31, O32

* Centre for European Economic Research (ZEW) P.O.Box 103443 68034 Mannheim Germany Phone: +49 621 1235-158 Fax: $+496211235-170$ E-mail: czarnitzki@zew.de
** University of Dortmund Vogelpothsweg 87 44227 Dortmund Germany Phone: +49 231 755-3152 Fax: +49 $231755-3155$ E-Mail: k.kraft@,wiso.uni-dortmund.de

\footnotetext{
*, ** The authors are very grateful to the Deutsche Finanzdatenbank (DFDB) and to Prof. Dr. Hans Peter Möller (Jahresabschlußdatenbank) for the very generous provision of their databases. We also thank the Deutsche Forschungsgemeinschaft (DFG) for financial support. In addition Thorsten Gliniars, Bianca Krol, Hartmut Meixner, Antonia Niederprüm, Stefan Schenk and Jörg Stank helped a lot in data processing.

This paper was partly written during a research stay of Dirk Czarnitzki at the University of California at Berkeley. I thank the UCB for the hospitality and the Volkswagen Foundation for financial support.
} 


\section{Introduction}

It is generally accepted that technical progress, along with human capital, has a major impact for the wealth and long-term growth of industrialized countries. Consequently economists have studied the causes and effects of innovation in theoretical and empirical studies for a long time.

Since Knight, Schumpeter and the beginning of the discussion on innovation, great emphasis has been placed on the central role of the entrepreneur in this process. As an example Kirzner (1985: 118), in line with the views of Hayek and Mises, emphasizes that a) the market is an entrepreneurial process, b) a learning process is central to the market and c) entrepreneurial activities are creative acts of discovery. In stark contrast to these statements on entrepreneurs, large firms are led by managers nowadays, and this leads to a classical principal-agent problem. Managers are mainly paid on the basis of a fixed salary and it is rather questionable whether they always act in the interest of the capital owners. According to Mises (1951: 13) an entrepreneur is defined by the following criterion: "There is a simple rule of thumb to tell entrepreneurs from nonentrepreneurs. The entrepreneurs are those on whom the incidence of losses on the capital employed falls." If this definition is used, the vast majority of the leading firms in all developed capitalist countries are not led by entrepreneurs. It remains to be investigated what consequences this has for the innovation process.

The question of control by the shareholders is related to firm leadership by managers. If capital is concentrated, the owners have clear incentives to monitor the managers, as given the large amount of capital invested - the return from this activity is significant. Moreover, in most cases the shareholders are very familiar with the situation of a firm and its environment, which reduces the problem of asymmetric information. This situation is different with diversified shares, as it is frequently the case in the modern corporation. With diversified shares the well-known free-rider problem arises, because every activity of an individual shareholder in order to increase efficiency of the management has to be shared with numerous other shareholders. Furthermore, the individual shareholder with widely diversified shares has neither the knowledge of the specific situation the firm is facing nor does she/he have a monetary incentive to intervene, because the financial stake is only small.

Recently some theoretical contributions have elaborated on this issue. Holmström (1989) discusses the principal-agent problem in the context of innovation. Zwiebel (1995) uses a two-period model with the expected remuneration of managers and considers the incentives for innovation if a manager is dismissed, provided the performance is below some level. Aghion et al. (1997) apply an intertemporal model to demonstrate that managers will invest less in innovation than others. They assume that the managers have private costs connected with innovation, and these determine their results. According to Zwiebel (1995) as well as Aghion et al. (1997) the manager-led 
firm is less innovative than the owner-led company. Both articles are based on riskneutrality on the part of the managers, which has no consequences in many circumstances. However, as will be discussed below, the attitude concerning risk determines the profit-orientation of the managerial remuneration in this context, and monetary incentives in turn affect the efforts of the managers.

Another strand of literature discusses possibilities to overcome the incentive problems in the principal-agency situation of the managerial firm. One possible instrument is the capital structure. It is argued (among others by Dewatripont and Tirole, 1994, Hart and Moore, 1995) that debt keeps a tight reign on managerial agency costs. The governance role of debt comes from the threat of bankruptcy (Aghion and Bolton, 1992), the reduction of free cash flow (Jensen, 1986) and monitoring by the creditors (Diamond, 1984).

There are numerous empirical papers on incentives for managers, such as the determination of remuneration and the behavior of the managerial firm with respect to growth, investment, profitability and other topics. However the relation between corporate governance and innovative activity is much less analyzed. The only empirical research on this issue, as far as we are aware, is our own (Czarnitzki and Kraft, 2004a,b).

The purpose of the present article is to report the results of an empirical study on the effects of the concentration of the capital shares and debt financing on innovative activity. For this purpose, a database on German manufacturing firms is used. In total we use information on 275 firms for the years 1982 to 1996, which leads to 2,793 observations. Innovation is specified by the number of patent applications per year. A major difference in comparison to earlier research in this field is the consideration of the capital structure.

\section{Theory}

The separation of ownership and control leads to a fundamental control and incentive problem. In the presence of asymmetric information it is a not a trivial task to design an incentive mechanism, where the agent (manager) works in the interest of the principal (shareholder). The problem has several dimensions, as it not only matters what the manager does, but also how much effort is put into reaching a certain task. Therefore, efficient effort levels are required for optimal allocation of resources. One simple solution would be control by the outside investors. Clearly this may be a possibility if there is a single dominant investor; however, this is rather unrealistic with widely diversified capital shares. Each shareholder faces the well-known free-rider problem, as the benefits of an initiative of one shareholder to improve the quality of management will be enjoyed by all other shareholders. The consequence will be underinvestment into monitoring the management and improving its decisions. "As a result, the 
management of a company with many shareholders will be under little pressure to perform well" (Hart, 2001).

Investment into $R \& D$ is clearly a risky project. In fact one of the most important tasks when innovative activity is analyzed is the consideration of the effect of risk. In the given context, risk has essentially two different effects: First, it affects the behavior of managers if they can control risk. Second, it determines the relation of fixed versus variable (profit-related) compensation for exogenously given risk.

\section{Incentives and Risk}

Starting with the second point, the incentive problem of managers has been analyzed in numerous articles. In the standard principal-agent problem as employed by Holmström and Milgrom (1987), pay-performance sensitivity depends on the parameters of the production function that transforms executive effort into output, and the distribution of a random variable which affects corporate performance. Pay-performance sensitivity is also influenced by the form of the manager's utility function, especially the degree of her/his absolute risk aversion ${ }^{1}$ and her/his cost of effort which is taken to be strictly convex. Holmström and Milgrom (1987) show that it is not ideal to make the remuneration totally output-dependent, but to use a combination of a fixed and a flexible share. The variable part of remuneration is a decreasing function of risk aversion. A contract which only depends on output without fixed remuneration would not be accepted by risk-averse managers. Thus, the optimal contract is a compromise between a partial insurance of the agent and the provision of incentives. ${ }^{2}$

The Holmström-Milgrom model has two limitations for the analysis of the present problem: dismissals are neglected and risk is exogenously given. Holmström and Milgrom do not consider the possibility of dismissals. However, if the manager does not meet a certain standard, in many cases she/he will be dismissed (for empirical evidence on this issue see Weisbach, 1988, Warner et al., 1988, Gilson, 1989, as well as Fizel and Louie, 1990). Hence the consideration of risk and risk aversion is even more complex than in the otherwise very useful model of Holmström and Milgrom (1987). If a

\footnotetext{
${ }^{1}$ The existing theoretical contributions on the relation of management-leadership and innovative activity like Zwiebel (1995) and Aghion et al. (1997) neglect risk aversion.

${ }^{2}$ There are many extensions and alternatives to this model: Holmström and Milgrom (1991) prove that, in multitask environments, fixed payments are useful because of the unobservability of some important tasks. Baker (1992) as well as Baker et al. (1994) consider the situation where the principal's objective cannot explicitly be the subject of an employment contract due to some vagueness in the objectives themselves. Given this vagueness it is quite likely that in such a situation a performance measure responds to the agent's actions in a different way than the principal's objective responds to these actions. If the objective is difficult to define, the firm will reduce the sensitivity of the incentives to the performance measure. The contract will be inefficient even if the agent is risk-neutral. Laffont and Tirole $(1986,1990,1993)$ develop a model on the incentive payments to regulated monopolists, which has been applied by Horn et al. (1994) to the theory of management incentives. Additional explanations of the limited application of profit-dependent payments are given by Perri (1994) and Palley (1997).
} 
manager pursues a risky project like $\mathrm{R} \& \mathrm{D}$, for example, a failure is definitely possible, and this would have a negative impact on profits. Given that there is some relation between profitability and managerial compensation, the manager's income would decrease as well. If the R\&D project is costly, the person might even be dismissed. Perhaps the Holmström-Milgrom model could be enlarged by the consideration of dismissals as a strong penalty, but based on the assumption that this possibility has an exogenously given probability.

This theory of income determination (possibly enlarged on the dismissal threat) may explain the variable and fixed shares of compensation. This will in turn determine the behavior of the agents, in particular, efforts react to flexible rewards. If an efficient R\&D management implies (quite realistically) effort on the part of the manager with a profit-share below one hundred percent, the manager will not exert the same effort level as the entrepreneur would do. As a consequence, either less R\&D will be carried out or the same R\&D expenditures will be allocated less efficiently.

The second effect of risk is even more pronounced. In contrast to what is assumed in the Holmström-Milgrom model, the manager is able to control the level of risk by allocating firm resources to more or less risky investments, when he or she tries to expand firm activities (in many cases above the profit-maximizing level). It is most likely that innovative activity is more risky than for example increasing marketing expenditures for existing products, raising the production capacity without altering the production process itself, or mergers and acquisitions. Hence the risk-averse manager will prefer less risky investments to risky projects, which is an argument against R\&D activities.

Things become even more complicated if the standard assumption of a risk-neutral entrepreneur is put into question. It is reasonable to assume risk-neutrality by the capital suppliers (investors) if these diversify their fortune over many different firms and thus effectively minimize risk. Such atomistic shareholders ask for a maximization of the expected value of investment irrespective of risk considerations. In contrast to atomistic shareholders, the classical entrepreneur very probably holds an undiversified portfolio and has concentrated his/her wealth in his/her firm. The owner therefore has good reasons to be risk-averse. If this scenario is true, the stock company with broadly diversified shares should be efficient and risk-neutral while the owner-led firm would be risk-averse.

\section{Growth incentives}

Whilst the consideration of risk is not trivial, there is an important second factor influencing R\&D activities, i.e. growth. Numerous studies have demonstrated that managers' salaries largely depend on the size of the firm in question and to a much smaller degree on profitability. For example, Baker et al. (1988) cite evidence that, as a general rule, the salary of top executives increases by $3 \%$ when the firm's sales increase by $10 \%$. In an examination of US companies, Jensen and Murphy (1990) found that a 
one dollar increase in the total wealth of capital owners (stock value and dividend) leads to only a three cent increase in management's total compensation. ${ }^{3}$ This will clearly lead to a growth orientation of managerial firms. Non-monetary determinants of managers' utility, such as status, power and prestige, are probably also related more closely to firm size than to profitability. Perhaps the capital market realizes the financial success, but public opinion is more impressed by employment figures and thus the personal influence increases with firm size. In a dynamic setting, the manager's income depends on firm growth, and since the beginning of this whole strand of literature, economists have hypothesized that the managerial firm is more growth-orientated than the owner-led company. Growth is, among other factors, determined by innovative activity (cf. e.g. Fagerberg, 1987).

Another argument supports the preferred use of innovative activity as an instrument generating growth. Public opinion concerning the expansion activities of managerial-led firms have recently become quite critical. However, this is mostly directed towards mergers and acquisitions and capacity expansions of established product lines. Amongst the public, investments into $R \& D$ are usually quite favorably evaluated, as they are expected to raise the competitiveness of the firm, and, in aggregate, that of the whole economy. Moreover, it increases growth possibilities and therefore income in the long run. Even politicians frequently use figures like R\&D and patent statistics as "success news" without questioning whether this is really an efficient allocation of resources. In such a situation, the management will face less objections when pursuing R\&D projects instead of other growth strategies. These arguments imply higher R\&D expenditures and more innovations by the managerial firm. Therefore, we have opposing incentives for the managers and it is an empirical question as to which are the predominant ones.

\section{Debt Financing}

A suggestion for solving the agency problem (or for reducing it) is by making commitments. As discussed above, profit-related pay is of limited use in the presence of risk-averse managers. An alternative commitment instrument is debt, because debt payments are fixed ex ante and cannot be circumvented. Therefore, debt commitments are "harder" than dividends and are able to control management in situations of asymmetric information (see Jensen, 1986, Hart and Moore, 1995, Harris and Raviv, 1990, Stulz, 1990, Zwiebel, 1996). If the management is unable to meet debt payments, the maximum penalty is bankruptcy. So this financial policy is effectively designed towards curtailing overspending on the part of the management, as this behavior increases the likelihood that pay-out commitments will be met. It can be ensured that

\footnotetext{
3 Many studies besides Jensen and Murphy (1990) have examined the dependence of management compensation on performance and found a limited relation (c.f. Gibbons and Murphy, 1990, Main, 1991, Kaplan, 1994a,b, Kraft and Niederprüm, 1999). In contrast, Hall and Liebman (1998) find quite a strong relationship between firm performance and managers' remuneration.
} 
internal funds are allocated to profitable investments instead of to personal aims of the top managers.

Another argument in favor of debt financing is the relative cost advantage compared to retained earnings and the issuing of new shares (cf. Hall, 2002). In addition, debt might be regarded as a positively valued signal about the true value of the firm in a situation of asymmetric information (see Ross, 1977). According to these views, increasing leverage has only beneficial effects. While debt is usually advantageous if the prospects are good, counter-arguments exist, too: if a firm faces a recession, the bankruptcy risk increases with its degree of leverage. This determines the disciplinary effect from above, and, hence, an optimal degree of leverage is sometimes postulated.

Since the work of Schumpeter it is assumed that debt itself (without consideration of leadership and incentive problems) has a negative correlation with innovativeness. First, $\mathrm{R} \& \mathrm{D}$ cannot be used as a collateral in credit negotiations with banks. In contrast to an investment in physical assets that is capitalized in the firm's balance sheet, R\&D is an expense and thus recognized as sunk cost at the time it is spent. Second, due to the uncertainty with respect to the outcome of an $R \& D$ project, an asymmetric information problem between borrower and lender emerges. As a result, banks and other possible investors are reluctant to finance such investments (see Hall, 2002).

\section{Empirical set-up and data}

The basis for the empirical investigation is a random sample of Western German jointstock companies. The main part of the database comprises of annual accounts collected by the Deutsche Finanzdatenbank. The number of firms observed has been extended by sampling firms from the Hoppenstedt "Bilanzdatenbank" and from annual reports. Information on the governance structure has been added from various sources (mainly the "wer gehört zu wem" publications of the Commerzbank). Furthermore, the number of patent applications per year have been linked to the firm level data. In total, the sample consists of 275 manufacturing firms observed in the period from 1982 to 1996 yielding an unbalanced panel of 2,973 firm-year observations. This database is enriched by information on the industry level in order to test for the impact of national or international competition.

The theory presented above deals with the difference between the classical entrepreneurial firm and the modern managerial firms. This question is tackled in the following way: firms with widely held stock are compared to those controlled by a dominant capital owner. We identify a dominant capital owner as a person or firm holding at least $25 \%$ of the capital shares. If the dominant capital owner is a family (which is not a rare case in Germany), we employ the joint capital share as the relevant yardstick. A dummy variable DISPERSION indicates whether the capital stock of a company is widely held (DISPERSION=1) or if a dominant owner exists (DISPERSION=0). This dummy variable takes unit value in about $19 \%$ of all cases. In 
line with the literature, we suppose that in firms with widely held stock (DISPERSION=1), management is insufficiently controlled.

While no information on $\mathrm{R} \& \mathrm{D}$ is available, patent counts represent an alternative measure of innovation. Although a patent measure differs from $R \& D^{4}$, both variables are highly correlated, because patents can only reasonably be filed (and granted) if corresponding R\&D efforts have been undertaken. Therefore, it appears justified to use patents as an indicator describing innovative activity. Patents may also have an advantage over R\&D: it is quite likely that large (managerial) firms conduct refinements on existing products and processes and therefore perform $\mathrm{R} \& \mathrm{D}$, but they do not invest into research on more radical inventions (see e.g. Henderson, 1993), which might be better qualified for filing patent applications. Thus patents might even reflect the really risky $R \& D$ investments better than mere $R \& D$ expenditure, which could lead to a better test of the risk argument in managers' incentive schemes. Clearly patents have also disadvantages as an innovation indicator, because some inventions are never patented and some patented knowledge is never implemented into new products or processes. The study analyzes the innovative activity of firms specified as the number of patent applications filed per year. This is a standard variable in studies on technical progress and is henceforth called PATENTS.

An important new feature of the present study compared to earlier ones (Czarnitzki and Kraft, 2004a, b) - in addition to the new data source - is the inclusion of the firms' financial structure. We consider the financial situation by the ratio of debt to total capital (DEBT). Debt has two potential effects in our empirical model: on the one hand, it is frequently argued that innovative activity has to be financed by internal resources like cash flow. The reasons for this are that bank managers are usually unable to evaluate the potential success of an $\mathrm{R} \& \mathrm{D}$ project and prefer to use physical assets to secure loans (see Hall, 1992). If a firm does not achieve sufficient cash flow and is in need of external financial support like debt, such a company will most likely show less innovative activity than others. Thus, the debt ratio is used as an indicator for external financing, and we expect a negative relation to innovative activity. On the other hand, as discussed above, management might be disciplined by debt commitment. Therefore, we introduce the interaction variable DISPERSION*DEBT in order to test for this hypothesis. The expected coefficient of this variable depends on the sign of the coefficient of DISPERSION: in the case of a positive coefficient of DISPERSION, firms with widely held stock would file more patents than others. We would conclude that the management does too much in this respect, at least if profit maximization is concerned. The interaction variable is then expected to have the opposite coefficient as the management is disciplined by the presence of debt commitment and the threat of a possible bankruptcy. The situation is a bit more complicated if the managers do not

\footnotetext{
${ }^{4}$ While $R \& D$ is an input of the innovative process, patents represent an (intermediate) output.
} 
conduct enough R\&D, as they want to avoid the risk and do not care about the long-run consequences for the firms' values (negative coefficient of DISPERSION). In principle, capital market control is expected to lead to an improved, if not optimal, situation. Commitment by debt implies a reduction of free cash flow and therefore the possibilities for any engagement above the absolutely necessary level are reduced. In the case where firms with dispersed ownership already show less innovative activity, it is however unlikely that DEBT*DISPERSION reduces innovativeness even further. The interaction variable would most likely have an insignificant coefficient in such a case. Less plausible, but not excludable, is the situation where external financing is used to increase the competitiveness of a firm in order to enable survival. New financial resources would be used for the introduction of new products and an improvement of the technology used. In this scenario, a positive coefficient of DEBT interacted with DISPERSION is possible. The management knows that the new resources have to be used efficiently as the probability of bankruptcy increases significantly otherwise. ${ }^{5}$ This argumentation is, however, in contradiction to the discussion on the general difficulties of financing innovation activities by external capital and therefore we find this argumentation less convincing. ${ }^{6}$

We also experimented with Cash-Flow as the internal source of financing innovation activities. It, however, turned out to be insignificant in all specification that have been considered. Therfore, we dropped it from the final estimations presented below.

Of course, a number of other control variables have to be taken into account. As the number of patent applications will be correlated with firm size, and firm size is probably related to the dispersion of capital shares, it is of primary importance to control for size effects. Here, the number of employees (EMP) and its squared value are used. $^{7}$

Three variables control for heterogeneous national and international competitive pressure: the share of sales exported (EXPORT) is measured on the individual firm level and describes the participation in international competition. A related variable is sales of foreign firms in the domestic market compared to total sales of both foreign and domestic firms (IMPORT). The import quota is measured at the industry level and expresses competitive pressure from other countries, which is highly significant for an open economy like Germany. Another variable controlling for domestic competition is

\footnotetext{
${ }^{5}$ It is beyond the scope of this paper to analyze the question, why some firms show a higher debt ratio than others. In our framework debt is predetermined, which is reflected in the use of DEBT in $t-1$.

${ }^{6}$ The analysis becomes even more complicated if the decision rights in different economic situations are considered. According to Aghion and Bolton (1992) the external investor should obtain full control if a firm performs poorly. If the firm performs well, the entrepreneur should have the decision rights. See also Kaplan and Stromberg (2003) for empirical evidence on these predictions.

${ }^{7}$ We also checked different specifications like $\log ($ EMP) or a number of size dummies, but the results do not depend on the particular specification of the size variables.
} 
seller concentration (CR6), which is defined as the sales share of the six largest companies in an industry. If a firm in our sample is active in more than a single industry, we assign the concentration index from that industry where the largest share of total sales volume is realized. We assume that the consideration of international trade and the concentration index allow to identify the degree of competitive pressure a firm faces.

Capital intensity (KAPINT) is defined as the total capital stock divided by the number of employees and indicates the technology intensity of firms' production. It is sometimes interpreted a proxy variable for barriers to entry. Technology intensity is clearly an argument in favor of innovativeness, while the role of barriers to entry and therefore competitive pressure is unclear and controversially discussed.

It is possible that younger firms are more innovative than more established firms, as the start-up phase usually goes hand in hand with the commercialization of inventions. As described above, the established firms might be more reluctant to introduce "fundamental" innovations. We take this possible relationship into account by including the log of firms' age in the analysis (ln(AGE)).

The opportunities for innovation will certainly differ among industries. Therefore 12 industry dummies are included in all regressions. Furthermore, we add 15 time dummies in order to control for changes in the general attitude to patent newly created knowledge and macroeconomic influences. Descriptive statistics of the variables used can be found in Table 1. All exogenous variables are lagged once, in order to treat the covariates as predetermined, and thus avoid endogeneity problems.

Table 1: Descriptive statistics

\begin{tabular}{|c|c|c|c|c|c|c|c|c|}
\hline \multirow[b]{2}{*}{ Variable } & \multicolumn{4}{|c|}{$\begin{array}{c}\text { DISPERSION }=0 \\
N_{0}=2,340\end{array}$} & \multicolumn{4}{|c|}{$\begin{array}{c}\text { DISPERSION }=1 \\
N_{1}=543\end{array}$} \\
\hline & Mean & Std. Dev. & Min. & Max. & Mean & Std. Dev. & Min. & Max. \\
\hline${\overline{\text { PATENT }_{i t}}}$ & 13.61 & 43.90 & 0 & 1088.00 & 87.30 & 247.67 & 0 & 1702.00 \\
\hline$(\mathrm{PATENT} / \mathrm{EMP} / 1,000)_{i t}$ & 3.35 & 7.45 & 0 & 105.37 & 5.48 & 9.08 & 0 & 76.87 \\
\hline$(\mathrm{EMP} / 1,000)_{i, t-1}$ & 3.44 & 8.34 & 0.01 & 61.62 & 8.67 & 17.06 & 0.05 & 71.81 \\
\hline $\ln (\mathrm{AGE})_{i, t-1}$ & 4.52 & 0.72 & 0 & 6.53 & 4.64 & 0.43 & 1.95 & 5.86 \\
\hline EXPORT $_{i, t-1}$ & 30.99 & 22.71 & 0 & 94.90 & 37.32 & 23.41 & 0 & 97.65 \\
\hline $\mathrm{KAPINT}_{i, t-1}$ & 0.22 & 0.43 & 0.00 & 9.75 & 0.46 & 1.22 & 0.03 & 10.04 \\
\hline $\operatorname{DEBT}_{i, t-1}$ & 0.39 & 0.19 & 0.03 & 0.97 & 0.36 & 0.19 & 0.02 & 0.85 \\
\hline $\mathrm{CR}_{i, t-1}$ & 23.94 & 18.43 & 6.50 & 88.00 & 23.79 & 16.72 & 6.50 & 88.00 \\
\hline IMPORT $_{i, t-1}$ & 0.29 & 0.20 & 0.01 & 1.36 & 0.35 & 0.23 & 0.03 & 0.99 \\
\hline
\end{tabular}

Note: 12 industry dummies and 15 time dummies not presented.

As Table 1 shows, the firms with widely dispersed stock are much larger: on average, such firms have about 8.7 thousand employees, whereas the sample mean for firms having a dominant capital owner is only 3.4 thousand. This leads, of course, to a large average difference in the number of patent applications filed per year: 87.3 applications for firms with DISPERSION=1, and only 13.6 for firms with dominant capital owners. We account for the correlation of DISPERSION and EMP in the upcoming analysis by 
estimating regressions not only on PATENT, but also on PATENT/EMP which can be interpreted as a kind of an innovation intensity. Rescaling PATENT by the number of employees reduces the size effects in the variable. On average, the firms controlled by a dominant capital owner show about 3.4 patent applications per thousand employees, whilst this figure is 5.48 for the other firms. Other interesting differences are that firms with widely dispersed stock realize higher export quotas and show a higher capital intensity, on average.

\section{Econometric Results}

As mentioned above, we consider PATENT as dependent variable, and run count data regressions; in particular Negative Binomial models (NegBin). ${ }^{8}$ Count data models are based on the assumption that the exogenous variables describe the move from 0 to 1 in much the same way as, for example, from 18 to 19 . However, many firms do no research at all and therefore they will never file a patent. Hence, in many cases there is a fundamental difference between observations with the value zero and those which have one or more patents. For this reason, the so-called zero-inflated models have been developed. The first equation analyzes whether the dependent variable is zero or larger than zero. Any observation larger than zero is adjusted to one, and then either a Logit or a Probit model is applied. In the second equation, the NegBin model is applied for those observations where the dependent variable is larger than zero (see e.g. Cameron and Trivedi, 1990, for details of econometric count data models). The share of censored observations in the full sample amounts to almost $49 \%$. In fact, the sample contains firms that never file a patent application during the whole period observed. Therefore, we also consider the subsample of patenting firms in the second stage. The subsample of firms that file at least one patent between 1982 to 1996 consists of 1,950 firm-year observations and the share of censored observations is less than $27 \%$.

Due to the fact that DISPERSION is correlated with EMP, we also estimate regressions using PATENT/EMP as dependent variable, in order to control for possible size effects. For this, we consider OLS estimations and Tobit regressions in order to account for the left-hand censoring of the dependent variable's distribution. One serious problem possibly occurring in Tobit estimations is heteroscedasticity, because a violation of the assumption of homoscedasticity leads not only to biased standard errors, but also to inconsistent coefficient estimates. Thus we consider multiplicative groupwise heteroscedasticity and replace the homoscedastic variance $\sigma$ by $\sigma_{i}=\sigma \exp \left(w_{i}^{\prime} \alpha\right)$, where $w_{i}$ represents the regressors entering the heteroscedasticity term and $\alpha$ the additional coefficients to be estimated. The regressors in the Tobit model's

\footnotetext{
8 The Poisson model is based on the assumption of equality of the conditional mean and variance $\operatorname{Var}(y \mid \boldsymbol{x})=\mathrm{E}(y \mid \boldsymbol{x})$. This restrictive assumption is released in the Negative Binomial model.
} 
heteroscedasticity term are seven firm size dummies (based on the number of employees), twelve industry dummies and fourteen time dummies.

Although our database would, in principle, allow controlling for firm-individual fixed effects in the regressions, we cannot unfortunately run panel models. Our main variable of interest, DISPERSION, does not change over time (except in a few very rare cases), i.e. we cannot identify the coefficient of DISPERSION in fixed effects regressions. Therefore, we rely on pooled cross-sectional estimations in this paper.

Table 2 presents the estimation results using the full sample. Before discussing the results, we will report some test statistics. We tested for heteroscedasticity in the Tobit model by computing LM tests (see e.g. Greene, 2000) using 7 size dummies $\left[L M\left(\left(\chi^{2}(7)\right)=179.27\right)\right], 12$ industry dummies $\left[\operatorname{LM}\left(\left(\chi^{2}(12)\right)=203.76\right)\right]$ and 14 time dummies $\left[\operatorname{LM}\left(\left(\chi^{2}(14)\right)=139.76\right)\right]$. The test statistics indicate that homoscedasticity is rejected in all cases. Thus the coefficients in the Tobit model might be misleading due to the violation of the homoscedasticity, and instead the results of the heteroscedastic Tobit model are preferable.

In the count data model, we tested for overdispersion and the $L R$ test indicated that the Poisson model (assuming no overdispersion) is clearly rejected $\left[\operatorname{LR}\left(\chi^{2}(1)\right)=43,464.41\right]$. In addition, we computed a Vuong test in order to check if the zero-inflated negative binomial (ZINB) outperforms the negative binomial regression. We include $\ln (\mathrm{EMP})$, $\ln (\mathrm{AGE}), \mathrm{EXPORT}$, IMPORT, CR6, DEBT, KAPINT in the inflation equation, and find that the Vuong statistic is significant at the $1 \%$ level $\left[\operatorname{VUONG}\left(\chi^{2}(1)\right)=8.72\right]$.

The main results are very robust over all different estimated models. The coefficient of DISPERSION is positively significant in all cases. It turns out that the positive growth incentives to innovate outweigh the negative risk incentives. Thus managers that are insufficiently controlled possibly spend too many resources on innovation compared to the profit-maximizing level.

Furthermore, DEBT shows a negative coefficient in the regressions (except in the zeroinflated negative binomial model). This supports the hypothesis that firms face financing constraints for R\&D. A very interesting result is that firms with widely held stock innovate more than those firms with a dominant capital owner. However, as the coefficient estimates DISPERSION*DEBT are negatively significant in all regressions, we can conclude that insufficiently shareholder-controlled managers are disciplined by the credit market. 
Table 2: Estimation results with full sample

\begin{tabular}{|c|c|c|c|c|c|}
\hline \multirow[b]{2}{*}{ Variab } & \multicolumn{3}{|c|}{$(\mathrm{PATENT} / \mathrm{EMP} / 1,000)_{i t}$} & \multicolumn{2}{|c|}{ PATENT $_{i t}$} \\
\hline & OLS & Tobit & $\begin{array}{l}\text { Tobit with hetero- } \\
\text { scedasticity }\end{array}$ & NegBin & $\mathrm{ZINB}^{\mathrm{b})}$ \\
\hline \multirow[t]{2}{*}{$(\mathrm{EMP} / 1,000)_{i, t-1}$} & $0.265 * * *$ & $0.720 * * *$ & $0.344 * * *$ & $0.351 * * *$ & $0.257 * * *$ \\
\hline & $(0.053)$ & $(0.084)$ & $(0.050)$ & $(0.014)$ & $(0.012)$ \\
\hline \multirow[t]{2}{*}{$(\mathrm{EMP} / 10,000)_{i, t-1}^{2}$} & $-0.426 * * *$ & $-1.120 * * *$ & $-0.502 * * *$ & $-0.470 * * *$ & $-0.335 * * *$ \\
\hline & $(0.091)$ & $(0.142)$ & $(0.080)$ & $(0.024)$ & $(0.019)$ \\
\hline \multirow[t]{2}{*}{$\ln (\mathrm{AGE})_{i, t-1}$} & 0.115 & 0.126 & -0.036 & -0.059 & $-0.084 *$ \\
\hline & $(0.172)$ & $(0.374)$ & $(0.226)$ & $(0.046)$ & $(0.045)$ \\
\hline \multirow[t]{2}{*}{ EXPORT $_{i, t-1}$} & $0.023 * *$ & $0.046 * * *$ & $0.039 * * *$ & $0.014 * * *$ & $0.016 * * *$ \\
\hline & $(0.010)$ & $(0.013)$ & $(0.009)$ & $(0.002)$ & $(0.002)$ \\
\hline \multirow[t]{2}{*}{$\mathrm{KAPINT}_{i, t-1}$} & $1.701 * * *$ & $2.181 * * *$ & $1.779 * * *$ & $0.161 * * *$ & $0.189 * * *$ \\
\hline & $(0.651)$ & $(0.365)$ & $(0.397)$ & $(0.057)$ & $(0.056)$ \\
\hline \multirow[t]{2}{*}{$\mathrm{DEBT}_{i, t-1}$} & $-1.403 * *$ & $-6.416 * * *$ & $-3.999 * * *$ & $-0.925 * * *$ & -0.343 \\
\hline & $(0.691)$ & $(1.572)$ & $(0.928)$ & $(0.233)$ & $(0.234)$ \\
\hline \multirow[t]{2}{*}{$\mathrm{CR} 6_{i, t-1}$} & $-0.049 * * *$ & $-0.095 * * *$ & $-0.034 *$ & $-0.014 * * *$ & $-0.005 *$ \\
\hline & $(0.017)$ & $(0.026)$ & $(0.018)$ & $(0.003)$ & $(0.003)$ \\
\hline \multirow[t]{2}{*}{$\operatorname{IMPORT}_{i, t-1}$} & 1.313 & -0.013 & 0.842 & 0.146 & $0.638 * *$ \\
\hline & $(0.890)$ & $(2.158)$ & $(1.167)$ & $(0.316)$ & $(0.287)$ \\
\hline \multirow[t]{2}{*}{ DISPERSION $_{i, t-1}$} & $4.626 * * *$ & $5.327 * * *$ & $3.178 * * *$ & $0.520 * * *$ & $0.470 * * *$ \\
\hline & $(1.066)$ & $(1.418)$ & $(0.919)$ & $(0.184)$ & $(0.154)$ \\
\hline \multirow[t]{2}{*}{ DISPERSION*DEBT $_{i, t-1}$} & $-8.187 * * *$ & $-8.710 * *$ & $-6.820 * * *$ & $-1.030 * *$ & $-1.100 * * *$ \\
\hline & $(2.558)$ & $(3.560)$ & $(2.372)$ & $(0.485)$ & $(0.420)$ \\
\hline \multirow[t]{2}{*}{ Intercept } & 1.016 & -2.657 & 0.286 & 0.171 & $0.612 *$ \\
\hline & $(1.378)$ & $(2.981)$ & $(1.962)$ & $(0.352)$ & $(0.369)$ \\
\hline \multirow[t]{2}{*}{ Industry dummies } & $F(14,2756)$ & $\chi^{2(12)}$ & $\chi^{2(12)}$ & $\chi^{2(12)}$ & $\chi 2(12)$ \\
\hline & $=22.00 * * *$ & $=558.31 * * *$ & $=149.62 * * *$ & $=580.26 * * *$ & $=588.87 * * *$ \\
\hline \multirow[t]{2}{*}{ Time dummies } & $F(12,2756)$ & $\chi 2(14)$ & $\chi 2(14)$ & $\chi 2(14)$ & $\chi 2(14)$ \\
\hline & $=2.41 * * *$ & $=24.67 * *$ & $=15.97$ & $=30.28 * * *$ & $=37.29 * * *$ \\
\hline \# of ob & 2,793 & 2,793 & 2,793 & 2,793 & 2,793 \\
\hline Log likelihood & - & $-5,900.02$ & $-5,552.92$ & $-6,580.48$ & $-6,411.55$ \\
\hline$R^{2} / \mathrm{McFadden} R^{2}$ & $0.190 /-$ & $-/ 0.095$ & $-/ 0.148$ & $-/ 0.178$ & $-/ 0.199$ \\
\hline
\end{tabular}

Standard errors in parentheses. $* * *(* *, *)$ indicate a significance level of $1 \%(5,10 \%)$.

a) The heteroscedasticity term includes 7 size dummies, 12 industry dummies and 14 time dummies (coefficient estimates not reported).

b) The inflation equation includes $\ln (\mathrm{EMP}), \ln (\mathrm{AGE}), \mathrm{EXPORT}$, IMPORT, CR6, DEBT, KAPINT (coefficient estimates not reported).

The other results are interesting as well: there is a strong size dependence of patenting activity. All models report a significant inversely u-shaped relationship. Moreover, competition affects innovative activity. The more firms are engaged on international markets (as measured by EXPORT) the more they rely on innovation activities. In contrast, the lower domestic competition firms face (as measured by CR6) the less they tend to innovate. In addition, the higher the capital-intensity the firms' production (KAPINT), the more they innovate. We do not find age effects, possibly due to high correlation with firm size. Finally, there are significant differences in innovating over industries and time (see joint hypothesis tests reported for industry and time dummies). 
As a further robustness check of our results we drop the firms that never filed any patent in the observed period. The sample size reduces to 1,950 observations using this subsample. Note that we still estimate Tobit models and zero-inflated negative binomial models, because even the patenting firms do not patent in every period. Therefore, we still want to take left-censoring of the distribution of the dependent variables into account.

The econometric test statistics yield similar results as reported for the full sample. The estimation results for using the subsample of patenting firms are reported in Table 3. In general, the estimated effects of the covariates are not as pronounced as in the full sample, but the main results on capital control hold in the subsample, too. There the estimated effects even become slightly stronger.

Table 3: Estimation results with subsample of patenting firms

Dependent variable:

$(\mathrm{PATENT} / \mathrm{EMP} / 1,000)_{i t}$

PATENT $_{i t}$

\begin{tabular}{|c|c|c|c|c|c|}
\hline Variable & OLS & Tobit & $\begin{array}{c}\text { Tobit with hetero- } \\
\text { scedasticity }\end{array}$ & NegBin & $\mathrm{ZINB}^{\mathrm{b})}$ \\
\hline \multirow[t]{2}{*}{$\overline{(\mathrm{EMP} / 1,000)_{i, t-1}}$} & $0.129 * *$ & $0.334 * * *$ & $0.147 * * *$ & $0.286 * * *$ & $0.258 * * *$ \\
\hline & $(0.059)$ & $(0.083)$ & $(0.041)$ & $(0.012)$ & $(0.014)$ \\
\hline \multirow[t]{2}{*}{$(\mathrm{EMP} / 10,000)_{i, t-1}^{2}$} & $-0.236 * *$ & $-0.539 * * *$ & $-0.225 * * *$ & $-0.374 * * *$ & $-0.334 * * *$ \\
\hline & $(0.097)$ & $(0.140)$ & $(0.063)$ & $(0.020)$ & $(0.021)$ \\
\hline \multirow[t]{2}{*}{$\ln (\mathrm{AGE})_{i, t-1}$} & -0.001 & -0.016 & 0.094 & $-0.076 *$ & -0.066 \\
\hline & $(0.232)$ & $(0.380)$ & $(0.194)$ & $(0.043)$ & $(0.052)$ \\
\hline \multirow[t]{2}{*}{$\mathrm{EXPORT}_{i, t-1}$} & $0.027 * *$ & $0.039 * * *$ & $0.028 * * *$ & $0.015 * * *$ & $0.014 * * *$ \\
\hline & $(0.014)$ & $(0.013)$ & $(0.009)$ & $(0.002)$ & $(0.003)$ \\
\hline \multirow[t]{2}{*}{$\mathrm{KAPINT}_{i, t-1}$} & $2.333 * * *$ & $2.489 * * *$ & $2.056 * * *$ & $0.150 * * *$ & $0.132 * *$ \\
\hline & $(0.806)$ & $(0.375)$ & $(0.371)$ & $(0.054)$ & $(0.053)$ \\
\hline \multirow[t]{2}{*}{$\operatorname{DEBT}_{i, t-1}$} & 0.337 & -1.410 & $-2.423 * * *$ & -0.298 & -0.302 \\
\hline & $(1.082)$ & (1.654) & $(0.880)$ & $(0.216)$ & $(0.225)$ \\
\hline \multirow[t]{2}{*}{$\mathrm{CR}_{i, t-1}$} & $-0.048 * *$ & $-0.055 * *$ & -0.002 & $-0.008 * *$ & $-0.006 * *$ \\
\hline & $(0.020)$ & $(0.026)$ & $(0.015)$ & $(0.003)$ & $(0.003)$ \\
\hline \multirow[t]{2}{*}{$\operatorname{IMPORT}_{i, t-1}$} & $2.281 *$ & $4.383 *$ & 3.377 & $0.717 * * *$ & $0.679 * *$ \\
\hline & (1.249) & $(2.269)$ & $(1.076)$ & $(0.278)$ & $(0.277)$ \\
\hline \multirow{2}{*}{ DISPERSION $_{i, t-1}$} & $5.700 * * *$ & $6.090 * * *$ & $2.692 * * *$ & $0.518 * * *$ & $0.496 * * *$ \\
\hline & $(1.333)$ & $(1.420)$ & $(0.909)$ & $(0.163)$ & $(0.164)$ \\
\hline \multirow[t]{2}{*}{ DISPERSION* $^{*} \mathrm{DEBT}_{i, t-1}$} & $-10.804 * * *$ & $-12.083 * * *$ & $-7.157 * * *$ & $-1.183 * * *$ & $-1.163 * * *$ \\
\hline & $(3.531)$ & $(3.633)$ & (2.291) & $(0.445)$ & $(0.438)$ \\
\hline \multirow[t]{2}{*}{ Intercept } & 2.359 & -0.079 & 0.514 & 0.424 & 0.518 \\
\hline & $(2.017)$ & $(3.132)$ & $(1.770)$ & $(0.350)$ & $(0.391)$ \\
\hline \multirow[t]{2}{*}{ Industry dummies } & $F(12,1913)$ & $\chi^{2(12)}$ & $\chi^{2(12)}$ & $\chi 2(12)$ & $\chi 2(12)$ \\
\hline & $=19.46^{* * *}$ & $=261.52 * * *$ & $=234.85 * * *$ & $=425.37 * * *$ & $=457.53 * * *$ \\
\hline \multirow[t]{2}{*}{ Time dummies } & $F(14,1913)$ & $\chi 2(14)$ & $\chi 2(14)$ & $\chi^{2(14)}$ & $\chi^{2(14)}$ \\
\hline & $=2.94 * * *$ & $=30.60 * * *$ & $=17.39 * * *$ & $=32.51 * * *$ & $=37.26^{* * *}$ \\
\hline \# of observations & 1,950 & 1,950 & 1,950 & 1,950 & 1,950 \\
\hline Log likelihood & - & $-5,622.28$ & $-5,184.31$ & $-6,174.25$ & $-6,132.98$ \\
\hline$R^{2} / \mathrm{McFadden} R^{2}$ & $0.157 /$ - & $-/ 0.044$ & $-/ 0.118$ & $-/ 0.151$ & $-/ 0.156$ \\
\hline
\end{tabular}

Standard errors in parentheses. $* * *(* *, *)$ indicate a significance level of $1 \%(5,10 \%)$.

a) The heteroscedasticity term includes 7 size dummies, 12 industry dummies and 14 time dummies (coefficient estimates not reported).

b) The inflation equation includes $\ln (\mathrm{EMP}), \ln (\mathrm{AGE}), \mathrm{EXPORT}$, IMPORT, CR6, DEBT, KAPINT (coefficient estimates not reported). 
Again, firms with widely held stock are more engaged in innovation activities, as the coefficient of DISPERSION is significantly positive in all regressions. Managers of those firms are disciplined by credit markets, because the interaction term DISPERSION*DEBT is significantly negative in all models. However, DEBT is no longer significantly different from zero in this setting. It is likely that possible financial constraints deter firms from innovation completely, because they are not able to raise sufficient external capital. Looking only at innovating firms, the role of financial constraints might be underestimated. Similar results are also reported by Czarnitzki (2002) who studies the impact of financial constraints on R\&D expenditure in a sample of German small and medium-sized manufacturing firms. The hypothesis that it is important to take the innovation status into account is also supported in the ZINB model. While DEBT is not significant in the continuous part of the patent distribution (PATENT $>0$ ), DEBT is significant in the inflation equation (coefficient estimate not reported in Table 3 ).

\section{Conclusion}

This paper considers the impact of management leadership of a firm in the presence of weak capital market control on the incentives for innovative activity. There are opposing effects at work, as managers will dislike the risk associated with R\&D projects but will like the growth effects of successful innovations. Hence the net effect of managerial leadership on innovative activity is unclear. Furthermore, we discuss the role of debt in $R \& D$ financing in general and in disciplining the management.

Subsequently the results from an empirical study are reported. We investigate the effect of a dispersed ownership of a firm compared to concentrated capital shares on the number of patents. The firms where the capital shares are broadly distributed file ceteris paribus more patents than the other companies.

Moreover, the role of debt financing is analyzed. Debt financing itself has a negative impact on innovativeness. This result is of interest, but most probably not very surprising. However, debt has another effect: it disciplines the management of firms with widely distributed shares and leads to behavior in line with firms which have a dominant capital owner. Hence debt really has the effect of reducing the agency problem suggested in theoretical literature. To the best of our knowledge, this is the first empirical test concerning the effect of debt financing on the behavior of managementled firms.

The implications of our empirical results appear to be quite interesting: management leadership does not only have negative effects. Firms led by managers have more patents than comparable companies. As patents are in a way the output of innovative activity (of an input like R\&D) managements' efforts to increase innovativeness cannot be a pure waste of resources. However this innovativeness might be above the profitmaximizing level, as the management puts more weight on growth and less on the rate 
of return on capital. As innovation usually has positive spill-overs it is frequently argued that the profit-maximizing firm does not carry out enough R\&D. Hence in this case perhaps the managerial firm is closer to the socially efficient level of innovativeness than the traditional capitalist firm, but of course not because the management wants to maximize social welfare.

\section{References}

Aghion, P. and P. Bolton, (1992), An Incomplete Contracts Approach to Financial Contracting, Review of Economic Studies 59, 473-94.

Aghion, P., M. Dewatripont and P. Rey (1997), Corporate Governance, Competition Policy and Industrial Policy, European Economic Review 41, 797-805.

Baker, G.P. (1992), Incentive Contracts and Performance Measurement, Journal of Political Economy 100, 598-614.

Baker, G.P., M.C. Jensen and K.J. Murphy (1988), Compensation and Incentives: Practice versus Theory, Journal of Finance 43, 593-616.

Baker, G.P., Gibbons, R. and K.J. Murphy (1994), Subjective Performance Measures in Optimal Incentive Contracts, Quarterly Journal of Economics 109, 1125-1156.

Cameron, A.C. and P.K. Trivedi (1998), Regression Analysis of Count Data, Cambridge.

Czarnitzki, D. (2002), Research and Development: Financial Constraints and the Role of Public Funding for Small and Medium-sized Enterprises, ZEW Discussion Paper No. 02-74, Mannheim.

Czarnitzki, D. and K. Kraft (2004a), Management Control and Innovative Activity, Review of Industrial Organization 24(1), 1-24.

Czarnitzki, D. and K. Kraft (2004b), Firm Leadership and Innovative Performance: Evidence from Seven EU Countries, Small Business Economics 22(5), 325-332.

Dewatripont, M. and J. Tirole (1994), A Theory of Debt and Equity: Diversity of Securities and Manager-Shareholder Congruence, Quarterly Journal of Economics 109 ,1027-1054.

Diamond, D.W. (1984), Financial Intermediation and Delegated Monitoring, Review of Economic Studies 51, 393-414.

Fagerberg, J. (1987), A Technology Gap Approach to Why Growth Rates Differ, Research Policy 16, 87-99.

Fizel, J.L. and K. Louie (1990), CEO Retention, Firm Performance and Corporate Governance, Managerial and Decision Economics 11, 167-176.

Gibbons, R. and K. Murphy (1990), Relative Performance Evaluation for Chief Executive Officers, Industrial and Labor Relations Review 43 (supplement), 30S-51S.

Gilson, S.C. (1989), Management Turnover and Financial Distress, Journal of Financial Economics 25, 241-262. 
Greene, W.H. (2000), Econometric Analysis, $4^{\text {th }}$ ed., New York.

Hall, B.H. (1992), Investment and Research and Development at the Firm Level: Does the Source of Financing Matter?, NBER Working Paper No. 4096, Cambridge.

Hall, B.H. (2002), The Financing of Research and Development, Oxford Review of Economic Policy 18(1), 35-51.

Hall, B.J. and J.B. Liebman (1998), Are CEOs Really Paid Like Bureaucrats?, Quarterly Journal of Economics 113, 653-691.

Harris, M and A. Raviv (1990), Capital Structure and the Informational Role of Debt, Journal of Finance 45, 425-458.

Hart, O. (2001), Financial Contracting, Journal of Economic Literature XXXIX(4), 1079-1100.

Hart, O. and J. Moore (1995), Debt and Seniority: An Analysis of the Role of Hard Claims in Constraining Management, American Economic Review 85, 567-585.

Henderson, R. (1993), Underinvestment and Incompetence as Responses to Radical Innovation; Evidence from the Photolithographic Alignment Equipment Industry, RAND Journal of Economics 24, 248-270.

Holmström, B. (1989), Agency Costs and Innovation, Journal of Economic Behavior and Organization 12, 305-327

Holmström, B. and P. Milgrom (1987), Aggregation and Linearity in the Provision of Intertemporal Incentives, Econometrica 55, 303-328.

Holmström, B. and P. Milgrom (1991), Multitask Principal-Agent Analyses: Incentive Contracts, Asset Ownership and Job Design, Journal of Law, Economics \& Organization 7 (Special Issue), 24-52.

Horn, H., H. Lang and S. Lundgren (1994), Competition, Long Run Contracts and Internal Inefficiencies in Firms, European Economic Review 38, 213-233.

Jensen, M.C. (1986), Agency Costs of Free Cash Flow, Corporate Finance, and Takeovers, American Economic Review 76, 323-329.

Jensen, M.C. and K.J. Murphy (1990a), Performance Pay and Top-Management Incentives, Journal of Political Economy 98, 225-264.

Kaplan, S.N. (1994a), Top Executives, Turnover, and Firm Performance in Germany, Journal of Law, Economics \& Organization 10, 142-159.

Kaplan, S.N. (1994b), Top Executive Rewards and Firm Performance: A Comparison of Japan and the United States, Journal of Political Economy 102, 510-546.

Kaplan, S.N. and P. Stromberg (2003), Financial Contracting Theory Meets the Real World: An Empirical Analysis of Venture Capital Contracts, Review of Economic Studies 70, 281-315.

Kirzner, I.M. (1985), Discovery and the Capitalist Process, University of Chicago Press: Chicago. 
Kraft, K. and A. Niederprüm (1999), Determinants of Management Compensation with RiskAverse Agents and Dispersed Ownership of the Firm, Journal of Economic Behavior and Organization 40, 17-27.

Laffont, J.J. and J. Tirole (1986), Using Cost Observation to Regulate Firms, Journal of Political Economy 94, 614-641.

Laffont, J.J. and J. Tirole (1990), The Regulation of Multiproduct Firms, Journal of Public Economics 43, 1-36.

Laffont, J.J. and J. Tirole (1993), A Theory of Incentives in Procurement and Regulation, MIT Press, Cambridge, Mass.

Main, B.G.M. (1991), Top Executive Pay and Performance, Managerial and Decision Economics 12, 219-229.

Mehran, H. (1995), Executive Compensation Structure, Ownership, and Firm Performance, Journal of Financial Economics 38, 163-184.

Mises, L. (1951), Profit and Loss, Consumers-Producers Economic Services, South Holland.

Palley, T.I. (1997), Managerial Turnover and the Theory of Short-Termism, Journal of Economic Behavior \& Organization 32, 547-557.

Perri, T.J. (1994), Influence Activity and Executive Compensation, Journal of Economic Behavior \& Organization 24, 169-181.

Ross, S.A. (1977), The Determination of Financial Structure: the Incentive-Signalling Approach, Bell Journal of Economics 8(1), 23-40.

Stulz, R. (1990), Managerial Discretion and Optimal Financing Policies, Journal of Financial Economics 32, 263-292.

Warner, J.B., R.C. Watts and K.H. Wruck (1988), Stock Prices and Top Management Changes, Journal of Financial Economics 20, 461-492.

Weisbach, M.S. (1988), Outside Directors and CEO Turnover, Journal of Financial Economics 20, 431-460.

Zwiebel, J. (1995), Corporate Conservatism and Relative Compensation, Journal of Political Economy 103, 1-25.

Zwiebel, J. (1996), Dynamic Capital Structure under Managerial Entrenchment, American Economic Review 86, 1197-1215. 